\title{
Three mechanisms of queen elimination in swarming honey bee colonies ${ }^{1}$
}

\author{
David C. GILLEY*, David R. TARPY \\ Department of Neurobiology and Behavior, Cornell University, Ithaca, NY 14853, USA \\ Received 8 September 2004 - Revised 17 December 2004 - Accepted 31 December 2004 \\ Published online 9 August 2005
}

\begin{abstract}
Queen elimination in honey bee colonies is a process by which all but one of the unmated queens produced during colony fission ("swarming") are eliminated from the parental nest. Queens are eliminated by three mechanisms: queen-queen duels, pre-emergence destruction, and departure with a secondary swarm. Here we describe each of these mechanisms of elimination and address important questions about queen elimination using detailed records of events from 13 observation-hive colonies undergoing queen elimination. We make the following conclusions. (1) The events during queen elimination occur in two distinct patterns: queen duels with secondary swarm departures, and no queen duels with pre-emergence destruction of all of the first-emerging queen's rivals. (2) The timing of secondary swarm departure is related to the events of queen elimination. (3) Queen duels are a common mechanism of elimination. (4) Workers play a significant but non-lethal role in queen elimination. (5) Queen elimination in European and African honey bee colonies is similar but the patterns of events may differ.
\end{abstract}

Swarming / queen elimination / queen duel / queen fight / pre-emergence destruction

\section{INTRODUCTION}

Swarming is a form of colony reproduction whereby the parental colony splits into one or more subunits each containing at least one sexual female (queen) and a fraction of the colony's workers. Reproduction by colony fission is widespread among social insects; it occurs in bees (Apidae: Meliponinae, Apinae; Winston, 1987; van Veen and Sommeijer, 2000), ants (Formicidae: Aenictinae, Dorylinae, Ecitoninae; Gotwald, 1995), and wasps (Vespidae: Polistinae; Jeanne, 1991). Swarming of honey bee (Apis mellifera L.) colonies can be divided functionally into two stages: queen rearing and queen elimination (Fig. 1). During queen rearing, a colony's worker population grows, 15-
20 queens are reared to adulthood inside specially constructed queen cells, and the primary swarm, consisting of the mother queen and approximately half of the colony's workers, departs from the nest. During queen elimination, the daughter queens within the natal nest emerge and either are killed in fights with rival queens (also known as "duels"), are killed by rival queens before emerging from their cells (also known as "pre-emergence destruction"), or depart in secondary swarms (also known as "afterswarms"); the remaining daughter queen inherits the natal nest. Queen elimination occupies a relatively brief period of a colony's life history (usually less than seven days), but the outcome of the process impacts the inclusive fitness of all colony members.

\footnotetext{
* Corresponding author: dgilley@tucson.ars.ag.gov

Current Address: USDA, ARS, Carl Hayden Bee Research Center, Tucson, AZ 85719, USA.

${ }^{1}$ Manuscript editor: Stan Schneider
} 


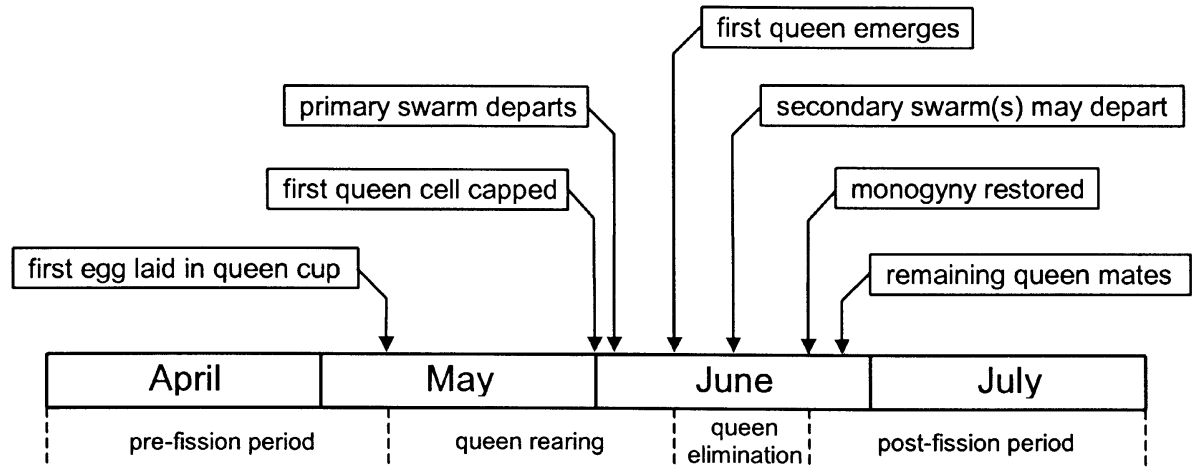

Figure 1. Timeline of the important events during reproductive fission ("swarming") of a European honey bee colony. The dates of events are typical for a colony in Ithaca, New York ( $42^{\circ} 26^{\prime} \mathrm{N}, 76^{\circ} 30^{\prime}$ W), a temperate climate.

Queen elimination has attracted increasing attention recently as an example of multi-level selection (Tarpy et al., 2004), group decision making (Gilley et al., 2003; Tarpy and Gilley, 2004), potential nepotism (Tarpy and Fletcher, 1998; Gilley, 2003), complex signalling (Gilley, 2001; Schneider et al., 2001; Schneider and Lewis, 2004), and a mechanism of invasive species success (Schneider and DeGrandiHoffman, 2003; Schneider et al., 2004). This recent research has made apparent some gaps in our knowledge of the events that occur within swarming honey bee colonies during queen elimination. Here we seek to advance our understanding of queen elimination in honey bee colonies by pointing out those gaps that we believe are most important and then addressing each using data from observational studies of queen elimination. First, however, we summarize what is known about queen elimination in honey bees by describing the three mechanisms of queen elimination.

\subsection{Queen-queen duels}

Lethal queen-queen combat is a common mechanism of queen elimination in Apis mellifera. Butz and Dietz (1994) described combat between mated queens that were introduced into the same colony, but there have been only a few detailed descriptions of combat between newly emerged virgin queens (Huber, 1814; Gilley, 2001; Weaver and Weaver, 1980; Ohtani, 1994). In the most recent description of newly emerged queens in a natural context (Gilley, 2001), queens were observed during "duels", i.e., from the moment two emerged queens were present simultaneously in the hive until one of these queens was killed ${ }^{2}$. The simultaneous presence of more than two queens was rare in the hives observed by Gilley (2001), but may be more common in honey bee subspecies that have been reported to rear large numbers of virgin queens such as A. mellifera sicula (Tiemann and Brückner, 1993; Hepburn and Radloff, 1998). During a duel, queens spend most of their time moving rapidly throughout the hive, emitting audible "piping" sounds, and investigating queen cells, from which they are usually chased away by workers. Dueling queens do not often come into contact with each other (once every $45 \mathrm{~min}$, on average), sometimes passing within $1 \mathrm{~cm}$ of

\footnotetext{
2 Because emerged queens often contact each other multiple times over an extended period, we prefer to follow Gilley's (2001) use of the term "duel" to describe the period of competition between two queens. It is convenient to have a label for this period and "duel", defined as a conflict between two antagonistic forces, is appropriate assuming that typically only two emerged queens are present. This usage reserves the term "fight" (used by many previous authors) for the contacts between queens that result in grappling and stinging attempts. Thus, a duel might include several contacts between queens, each of which can result in fighting or fleeing. Queens are eliminated by fights but since the outcome of a fight may depend on other events that occur during a duel, we consider the entire duel as a mechanism of elimination.
} 
one another without reacting noticeably. They may also "hide" by placing themselves within worker cells for several hours. When queens contact each other, they either part following antennal contact, or they grapple together, using their legs and mandibles to position themselves to sting their rival. The stimulus that triggers grappling behavior is unknown, but is located on the queens' abdominal tergites (Pflugfelder and Koeniger, 2003). Grappling contacts last from $4 \mathrm{~s}$ to $15 \mathrm{~min}$ and usually result in the death or wounding of one queen, but can end without a successful sting by either queen. Sometimes when rival queens are near each other, rather than fighting, one queen points the tip of her abdomen at her opponent and ejects fecal material onto her (often referred to as "spraying"; Page and Erickson, 1986; Post et al., 1987; Page et al., 1988; Bernasconi et al., 1999, 2000; Gilley, 2001; Tarpy and Fletcher, 2003). Workers interact extensively with queens during duels (Huber, 1814; Weaver and Weaver, 1980; Ohtani, 1994; Gilley, 2001). The variability in the rates of these interactions among dueling queens has led some to investigate whether workers play a role in selecting which queen will win the series of duels and inherit the nest. Several studies have demonstrated non-random outcomes of queen duels with respect to particular queen characteristics or behavior, which may be due in part to actions by the workers. For example, queens survive with higher probabilities when they are related to the workers in a hive (Tarpy and Fletcher, 1998; but see Gilley, 2003), when they are older than their opponents (Tarpy et al., 2000), and when they are more frequently shaken by workers (Schneider et al., 2001).

\subsection{Pre-emergence destruction}

An emerged queen sometimes eliminates her rivals before they emerge from their cells. She does this by spending from several minutes to an hour chewing a 3-5 $\mathrm{mm}$ diameter hole in the side wall of a queen cell and then repeatedly pushing the tip of her abdomen into the hole, stinging the cell's occupant (Huber, 1814; Boch et al., 1979). Queens destroy cells that are close to emergence before cells that contain immature pupae, thereby eliminating their most dangerous rivals first (Caron and Greve, 1979;
Harano and Obara, 2004). Sometimes, queens attacking cells do not sting the occupant, instead departing after having only chewed a hole in the cell. Stinging occurs most often when a cell's occupant has pupated and is ready to emerge (Huber, 1814; Gilley, unpublished data). Workers near a cell that is under attack either ignore the visiting queen or enlarge the hole that she chews in the wall of the cell (Huber, 1814; Gilley, unpublished data). The workers eventually tear down queen cells that are damaged by emerged queens and dispose of the queen pupae that occupied them.

\subsection{Secondary swarm departure}

The departure of a colony's primary swarm (i.e., that containing the mother queen) from observation hives has been described in detail by a number of investigators (e.g., Huber, 1814; Allen, 1956; Lindauer, 1961; Martin, 1963; Caron, 1970). Secondary swarms typically depart with fewer workers than primary swarms, and can contain several young queens (Huber, 1814; this may be especially common in African subspecies, Hepburn and Radloff, 1998), but are similar to primary swarms with respect to the mechanics of the swarming process (Gilley, personal observation). Swarming begins with a rapid running of workers on the comb near the hive entrance. This behavior spreads throughout the hive within 3-4 minutes, and is followed by a massive rush to the nest entrance opening (Caron, 1970). The queen either joins the exodus voluntarily (Caron, 1970) or is forced out by the workers (Allen, 1956; Caron, 1970), after which she may attempt to reenter the hive (Caron, 1970). The bees fly about near the entrance of the hive until most of the colony has departed $(95 \%$ of workers and drones initially leave the hive, though many return within one hour; Caron, 1970), and then cluster on a tree branch or other nearby object to begin choosing a new nest site. Sometimes a queen does not leave the hive or fails to join the swarm cluster, in which case the workers return to the hive in approximately 30 min, usually swarming again the following day (Allen, 1956; Caron, 1970).

Though queens are not killed by departure with a secondary swarm, the chance that a secondary swarm survives its first winter is very low in temperate climates such as most of North America (Seeley, 1978). Thus, departure with 
a secondary swarm is extremely costly relative to inheriting the nest and we consider it as a mechanism of elimination alongside queen duels and pre-emergence destruction.

\subsection{Outstanding questions about queen elimination}

To understand how natural selection has shaped both queen and worker behavior to maximize their inclusive fitness, we believe we need to address the following outstanding questions about the elimination of queens from honey bee nests.

1. What is the typical pattern of events during queen elimination?

2. When do secondary swarms depart in relation to other events during queen elimination?

3. What are the relative roles of swarm departure, queen duels, and pre-emergence destruction in determining the outcome of queen elimination?

4. What role do workers play in the elimination of queens?

5 . Does the biology of queen elimination differ between European (A. mellifera ligustica) and African (A. mellifera scutellata) honey bees?

\section{MATERIALS AND METHODS}

To observe in detail the behavior of both workers and queens during queen elimination, five honey bee colonies were established in May and June, 1998, in Ithaca, New York. The behavior of the workers during the queen duels that took place within these colonies was reported previously by Gilley (2001), however, the results presented here are novel. Each colony was housed in a three-frame observation hive (approximate capacity of 6000 workers) headed by a European honey bee queen (Apis mellifera ligustica). Colony establishment was staggered to reduce the chance that queen elimination was missed because only one colony could be observed at a time. To promote afterswarming and queen elimination, each hive was well stocked with workers and brood from its parent colony. The observation hives were similar to those used previously (Gilley, 1998) but with larger internal dimensions $(74.0 \times 45.8 \times$ $4.0 \mathrm{~cm}$ ) and shorter entrance tunnels $(20 \mathrm{~cm})$ to facilitate the exodus of bees during swarming. Wooden slats were inserted in the spaces around the frames to ensure that the queens could be viewed at all times. Each colony was monitored as follows when it began to rear queens. The date and time that the workers sealed each queen cell were noted and used to estimate the earliest time that the queen might emerge from each cell (typically $7 \mathrm{~d}$ after sealing). When the cap of each cell became dark and smooth (a sign that queen emergence was imminent), the cell was inspected every $10 \mathrm{~min}$. Queens were observed continuously from when they emerged to when they were eliminated from the nest, often requiring four or more observers working in shifts. We refer to these colonies as Colonies E1-E5.

To strengthen the power of our results and to enable us to address all of the questions introduced above (e.g., Question \#5), we include in our analyses data from several colonies that we did not observe directly. The events in these additional colonies are described narratively by their authors (Allen, 1956; Fletcher, 1978), from which we have reconstructed the sequence of events with regard to queen elimination to enable comparison with Colonies E1-E5. Colony E6 (Allen, 1956) was located at the North of Scotland College of Agriculture, housed in an observation hive that contained three frames of brood and approximately 4500 bees when observations began on 18 May, 1954. The honey bee subspecies is not identified, but is assumed to be a European subspecies. Colonies A1-A7 (Fletcher, 1978) are African honey bee colonies (Apis mellifera scutellata, previously known as Apis mellifera adansonii) located in Pietermaritzburg, South Africa, housed in twoframe observation hives that initially contained 2500-3500 bees and brood of all ages. Together, these 13 colonies are the only colonies that we know of for which there exist detailed within-hive observations of queen elimination.

\section{RESULTS}

The emergence of queens and the events that led to a restoration of monogyny in six European and seven African honey bee colonies are described in Tables I and II. A flowchart of the events during queen elimination in these 13 colonies is shown in Figure 2. The fates of the queens reared by the 13 colonies examined in this study are summarized in Table III. The proportion of queens eliminated by each of the three mechanisms for several types of colonies is described in Table IV. Colonies with at least one secondary swarm departure had fewer queens killed in cells and more queens killed in duels than colonies with no secondary swarm departures $(2 \times 2$ Chi-Square test of independence, d.f. $=1, P<0.001)$. Colonies with at least 
Table I. The events associated with swarming within six European honey bee colonies (data for Colony E6 from Allen, 1956).

\begin{tabular}{|c|c|c|c|c|}
\hline Colony & Queen & Emergence date \& time & Fate & Fate date $\&$ time \\
\hline \multirow[t]{13}{*}{ E1 } & mother & unknown & departed with primary swarm & $6 / 9 \quad 09: 00$ \\
\hline & $\mathrm{a}$ & $6 / 11 \quad 13: 25$ & killed in duel with b & $6 / 13 \quad 24: 00$ \\
\hline & $\mathrm{b}$ & $6 / 13 \quad 24: 00$ & killed in duel with $d$ & $6 / 20 \quad 02: 00$ \\
\hline & $\mathrm{c}$ & 6/15 11:06 & departed with secondary swarm 1 & $6 / 15 \quad 11: 25$ \\
\hline & $\mathrm{d}$ & $6 / 19 \quad 23: 15$ & killed in duel with e & $6 / 20 \quad 17: 00$ \\
\hline & $\mathrm{e}$ & $6 / 20 \quad 10: 00$ & killed in duel with? & 6/22 ??:?? \\
\hline & $\mathrm{f}$ & $6 / 22 \quad 22: 40$ & killed in duel with e & $6 / 22 \quad 23: 00$ \\
\hline & $\mathrm{g}$ & $6 / 23 \quad 15: 00$ & killed in duel with? & 6/23 ??:?? \\
\hline & $\mathrm{h}$ & $6 / 23 \quad 16: 50$ & killed in duel with? & $6 / 24 \quad 07: 25$ \\
\hline & $\mathrm{i}$ & $6 / 25 \quad 06: 40$ & departed with secondary swarm 2 & $6 / 27 \quad 10: 55$ \\
\hline & $\mathrm{j}$ & $6 / 27 \quad 11: 35$ & killed in duel with? & 6/28 ??:?? \\
\hline & $\mathrm{k}$ & $6 / 29 \quad 07: 00$ & inherited colony & $6 / 29 \quad 12: 45$ \\
\hline & 1 & $6 / 29 \quad 07: 30$ & killed in duel with $\mathrm{k}$ & $6 / 29 \quad 12: 45$ \\
\hline \multirow[t]{5}{*}{ E2 } & mother & unknown & departed with primary swarm & ?/?? ??:?? \\
\hline & a & $7 / 7 \quad 07: 30$ & killed in duel with c & $7 / 12 \quad 21: 57$ \\
\hline & $\mathrm{b}$ & $7 / 11 \quad 22: 15$ & killed in duel with a & $7 / 12 \quad 15: 15$ \\
\hline & $\mathrm{c}$ & 7/12 08:00 & inherited colony & $7 / 13 \quad 15: 26$ \\
\hline & $\mathrm{d}$ & $7 / 13 \quad 10: 00$ & killed in duel with c & $7 / 13 \quad 15: 26$ \\
\hline \multirow[t]{6}{*}{ E3 } & mother & unknown & departed with primary swarm & $6 / 21 \quad 11: 30$ \\
\hline & $\mathrm{a}$ & $6 / 25 \quad 08: 45$ & inherited colony & $6 / 26 \quad 16: 30$ \\
\hline & $\mathrm{b}$ & - & killed in cell by a & $6 / 25 \quad 09: 40$ \\
\hline & $\mathrm{c}$ & - & killed in cell by a & $6 / 25 \quad 15: 45$ \\
\hline & $\mathrm{d}$ & - & cell attacked by a & $6 / 25 \quad 23: 30$ \\
\hline & $\mathrm{e}$ & - & cell attacked by a & $6 / 26 \quad 16: 30$ \\
\hline \multirow[t]{10}{*}{ E4 } & mother & unknown & departed with primary swarm & $6 / 22 \quad 12: 20$ \\
\hline & a & $7 / 5 \sim 01: 45$ & inherited colony & 7/6 ??:?? \\
\hline & $\mathrm{b}$ & $7 / 5 \sim 01: 45$ & killed in duel with a & $7 / 5 \quad 01: 45$ \\
\hline & $\mathrm{c}$ & - & cell attacked by a & $7 / 5 \quad 03: 35$ \\
\hline & $\mathrm{d}$ & - & cell attacked by a & $7 / 5 \quad 04: 40$ \\
\hline & $\mathrm{e}$ & - & cell attacked by a & $7 / 5 \quad 06: 30$ \\
\hline & $\mathrm{f}$ & - & cell destroyed by ? & $7 / 5 \quad 18: 40$ \\
\hline & g & - & killed in cell by a & $7 / 5 \quad 20: 50$ \\
\hline & $\mathrm{h}$ & - & cell destroyed by ? & $7 / 5 \quad 23: 50$ \\
\hline & $\mathrm{i}$ & - & cell destroyed by ? & 7/6 ??:?? \\
\hline \multirow[t]{4}{*}{ E5 } & mother & unknown & missing & 6/21 ??:?? \\
\hline & a & 6/27 17:09 & departed with secondary swarm & $7 / 3 \quad 11: 00$ \\
\hline & $\mathrm{b}$ & 6/29 03:00 & killed in duel with a & 6/29 03:00 \\
\hline & $\mathrm{c}$ & - & killed in cell by a & $6 / 30 \quad 08: 02$ \\
\hline
\end{tabular}


Table I. Continued.

\begin{tabular}{|c|c|c|c|c|}
\hline Colony & Queen & Emergence date \& time & Fate & Fate date $\&$ time \\
\hline \multirow{12}{*}{ E6 } & $\mathrm{d}$ & $6 / 30 \quad 08: 30$ & killed in duel with a & $6 / 30 \quad 17: 15$ \\
\hline & $\mathrm{e}$ & - & cell attacked by a & $7 / 1 \quad 02: 35$ \\
\hline & $\mathrm{f}$ & - & cell attacked by a & $7 / 1 \quad 06: 42$ \\
\hline & $\mathrm{g}$ & $7 / 3 \quad 16: 35$ & inherited colony & $7 / 3 \quad 16: 35$ \\
\hline & mother & unknown & departed with primary swarm & $7 / 7 \quad 15: 35$ \\
\hline & a & $7 / 12<12: 00$ & departed with secondary swarm 1 & $7 / 14 \quad 12: 56$ \\
\hline & $\mathrm{b}$ & - & cut down by workers* & 7/19* ??:?? \\
\hline & $\mathrm{c}$ & - & dead queen removed by workers & 7/4 ??:?? \\
\hline & d & $7 / 13<12: 00$ & departed with secondary swarm 2 & $7 / 19 \quad 12: 40$ \\
\hline & $\mathrm{e}$ & $7 / 19 \quad 12: 30$ & departed with secondary swarm 2 & $7 / 19 \quad 12: 40$ \\
\hline & $\mathrm{f}$ & $7 / 19 \quad 12: 35$ & inherited colony & 7/19 $12: 40$ \\
\hline & $\mathrm{g}$ & - & cut down by workers* & 7/19*??:?? \\
\hline
\end{tabular}

* The destruction of cells $\mathrm{b}$ and $\mathrm{g}$ following the departure of the final swarm on 7/19 is likely to have coincided with attacks by Queen $\mathrm{f}$ on these cells, though no mention is made of these events by Allen (1956).

Table II. The events associated with swarming within seven African honey bee colonies (modified from Fletcher, 1978).

\begin{tabular}{|c|c|c|c|c|}
\hline Colony & Queen & Emergence date \& time & Fate & Fate date \& time \\
\hline \multirow[t]{8}{*}{ A1 } & mother & unknown & departed with primary swarm & unknown \\
\hline & a & $1 / 14 \quad 05: 24$ & inherited colony & unknown \\
\hline & $\mathrm{b}$ & - & killed in cell by a & unknown \\
\hline & $\mathrm{c}$ & - & cell attacked by a & unknown \\
\hline & $\mathrm{d}$ & - & cell attacked by a & unknown \\
\hline & $\mathrm{e}$ & - & cell attacked by a & unknown \\
\hline & $\mathrm{f}$ & - & destroyed by workers after sealing & unknown \\
\hline & g & - & destroyed by workers after sealing & unknown \\
\hline \multirow[t]{9}{*}{ A2 } & mother & unknown & departed with primary swarm & unknown \\
\hline & a & 2/6 02:08 & killed in duel with $\mathrm{c}$ & 2/7 ??:?? \\
\hline & $\mathrm{b}$ & 2/9 ??:?? & killed in duel with $\mathrm{d}$ e or $\mathrm{f}$ & 2/9 ??:?? \\
\hline & $\mathrm{c}$ & 2/7 $14: 08$ & departed with secondary swarm & 2/9 08:46 \\
\hline & $\mathrm{d}$ & 2/9 ??:?? & killed in duel with $b$ e or $f$ & 2/9 ??:?? \\
\hline & $\mathrm{e}$ & 2/9 ??:?? & killed in duel with $b \mathrm{~d}$ or $\mathrm{f}$ & 2/9 ??:?? \\
\hline & $\mathrm{f}$ & 2/9 ??:?? & inherited colony & unknown \\
\hline & $\mathrm{g}$ & - & cell attacked by $\mathrm{f}(?)$ & unknown \\
\hline & $\mathrm{h}$ & - & cell attacked by $\mathrm{f}(?)$ & unknown \\
\hline \multirow[t]{2}{*}{ A3 } & mother & unknown & departed with primary swarm & unknown \\
\hline & a & $5 / 22 \quad 09: 55$ & inherited colony & unknown \\
\hline
\end{tabular}


Table II. Continued.

\begin{tabular}{|c|c|c|c|c|}
\hline Colony & Queen & Emergence date \& time & Fate & Fate date $\&$ time \\
\hline & $\mathrm{b}$ & - & cell attacked by a & unknown \\
\hline \multirow[t]{13}{*}{ A4 } & mother & unknown & departed with primary swarm & unknown \\
\hline & $\mathrm{a}$ & $11 / 12 \quad 07: 45$ & killed in duel with $\mathrm{d}$ & 11/12 ??:?? \\
\hline & $\mathrm{b}$ & 11/12 08:01 & killed in duel with a & 11/12 ??:?? \\
\hline & $\mathrm{c}$ & 11/15 10:17 & departed with secondary swarm & 11/15 10:17 \\
\hline & d & 11/12 09:44 & departed with secondary swarm & 11/15 10:17 \\
\hline & $\mathrm{e}$ & 11/13 $09: 50$ & departed with secondary swarm & 11/15 10:17 \\
\hline & $\mathrm{f}$ & 11/15 10:17 & departed with secondary swarm & 11/15 10:17 \\
\hline & g & $11 / 16>06: 59$ & killed in duel with $\mathrm{h} 1 \mathrm{j}$ or $\mathrm{k}$ & 11/16 ??:?? \\
\hline & $\mathrm{h}$ & $11 / 15 \quad 15: 56$ & killed in duel with $\mathrm{g} 1 \mathrm{j}$ or $\mathrm{k}$ & 11/16 ??:?? \\
\hline & $\mathrm{i}$ & - & destroyed by workers after sealing & unknown \\
\hline & $\mathrm{j}$ & $11 / 16>06: 59$ & inherited colony & 11/16 ??:?? \\
\hline & $\mathrm{k}$ & $11 / 16>06: 59$ & killed in duel with $\mathrm{g} \mathrm{h} \mathrm{j}$ or $\mathrm{l}$ & 11/16 ??:?? \\
\hline & 1 & $11 / 16>06: 59$ & killed in duel with $\mathrm{g} \mathrm{h} \mathrm{j}$ or $\mathrm{k}$ & 11/16 ??:?? \\
\hline \multirow[t]{3}{*}{ A5 } & mother & unknown & departed with primary swarm & unknown \\
\hline & a & $12 / 2 \quad 04: 40$ & inherited colony & unknown \\
\hline & $\mathrm{b}$ & - & cell attacked by a & unknown \\
\hline \multirow[t]{3}{*}{ A6 } & mother & unknown & departed with primary swarm & unknown \\
\hline & a & $12 / 2 \quad 11: 40$ & inherited colony & unknown \\
\hline & $\mathrm{b}$ & - & cell attacked by a & unknown \\
\hline \multirow[t]{11}{*}{ A7 } & mother & unknown & departed with primary swarm & unknown \\
\hline & a & $4 / 24 \quad 11: 35$ & departed with secondary swarm 2 & $4 / 27 \quad 08: 38$ \\
\hline & $\mathrm{b}$ & 4/24 13:00 & killed in duel with a (?) & $4 / 25$ or early $4 / 26$ \\
\hline & $\mathrm{c}$ & 4/25 00:00 & departed with secondary swarm 1 & $4 / 26 \quad 12: 15$ \\
\hline & d & $4 / 26 \quad 12: 15$ & departed with secondary swarm 1 & $4 / 26 \quad 12: 15$ \\
\hline & $\mathrm{e}$ & $4 / 27 \quad 08: 38$ & \multirow{6}{*}{$\begin{array}{l}\text { These queens engaged } \\
\text { in a series of duels until } \\
\text { only one queen remained } \\
\text { alive to inherit the nest. }\end{array}$} & 4/28 ??:?? \\
\hline & $\mathrm{f}$ & $4 / 28$ & & 4/28 ??:?? \\
\hline & $\mathrm{g}$ & $4 / 28$ & & 4/28 ??:?? \\
\hline & $\mathrm{h}$ & $4 / 28$ & & 4/28 ??:?? \\
\hline & $\mathrm{i}$ & $4 / 28$ & & 4/28 ??:?? \\
\hline & $\mathrm{j}$ & $4 / 28$ & & 4/28 ??:?? \\
\hline
\end{tabular}




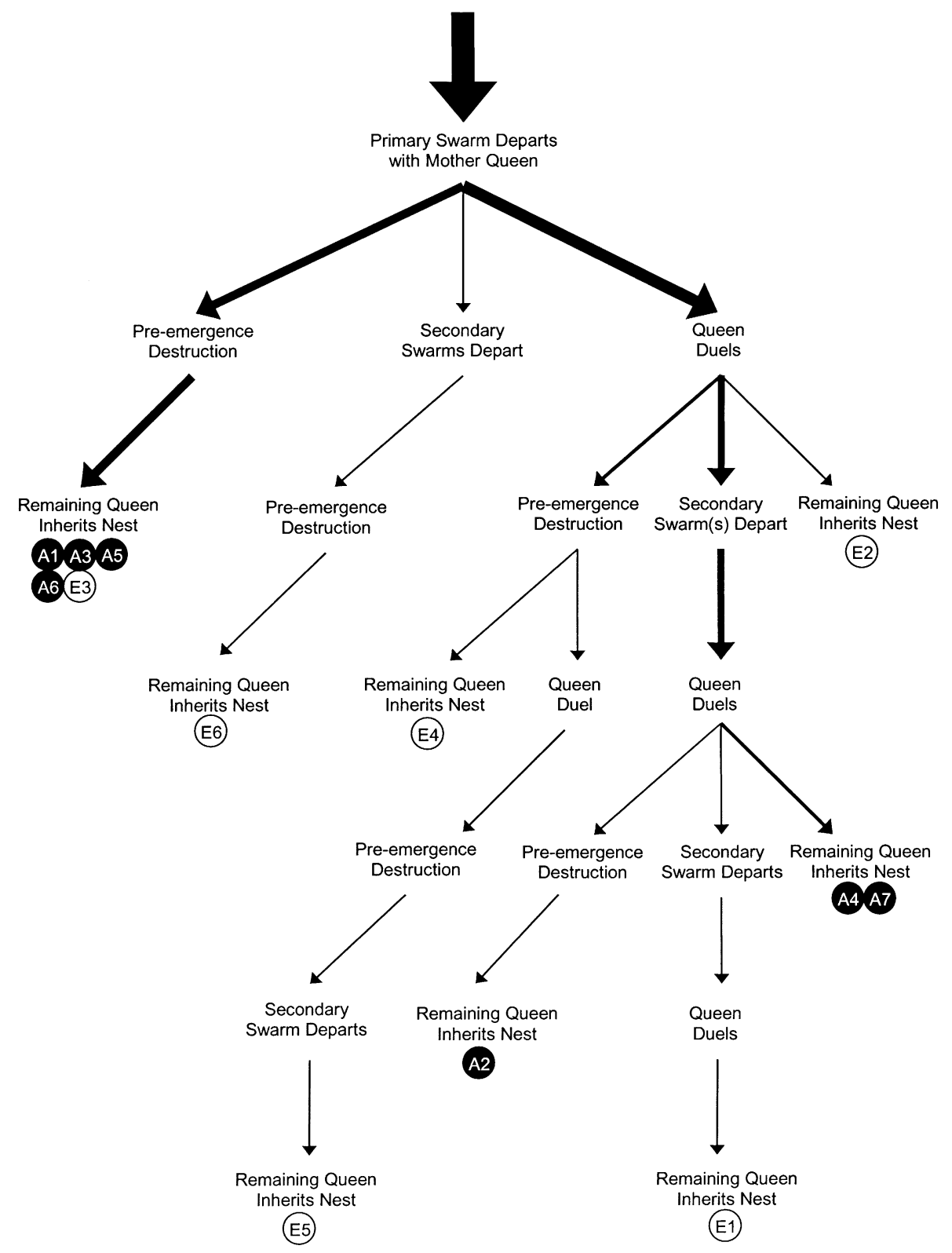

Figure 2. Flowchart of the events following departure of the mother queen for 13 honey bee colonies. The width of each arrow represents the number of colonies following that sequence of events. The endpoint for each colony, the inheritance of the nest by the remaining queen, is labeled with the colony's identity in a white circle (European colonies) or a black circle (African colonies).

one duel tended to have fewer queens killed in cells and more queens depart with secondary swarms than colonies without duels, though this trend was only marginally significant
$(2 \times 2$ Chi-Square test of independence, d.f. $=$ $1, P=0.063)$. Colonies with at least one preemergence death did not differ significantly from colonies without pre-emergence death in 
Table III. The fate of 83 queens reared in 13 honey bee colonies.

\begin{tabular}{cccccc}
\hline & \multicolumn{5}{c}{ Number of queens } \\
\cline { 2 - 6 } Colony & killed in cells & killed in duels & left in swarms & inherited colony & total \\
\hline E1 & 0 & 9 & 2 & 1 & 12 \\
E2 & 0 & 3 & 0 & 1 & 4 \\
E3 & 4 & 0 & 0 & 1 & 5 \\
E4 & 7 & 1 & 0 & 1 & 9 \\
E5 & 3 & 2 & 1 & 1 & 7 \\
E6 & 2 & 0 & 3 & 1 & 6 \\
A1 & 4 & 0 & 0 & 1 & 5 \\
A2 & 2 & 4 & 1 & 1 & 8 \\
A3 & 1 & 0 & 0 & 1 & 2 \\
A4 & 0 & 6 & 4 & 1 & 11 \\
A5 & 1 & 0 & 0 & 1 & 2 \\
A6 & 1 & 0 & 0 & 1 & 2 \\
A7 & 0 & 6 & 31 & 1 & 10 \\
\hline Total & 25 & $(37.3 \%)$ & $(16.9 \%)$ & $(15.7 \%)$ & 83 \\
\hline
\end{tabular}

Table IV. The proportion of queens eliminated by each of three mechanisms for several types of colonies.

\begin{tabular}{lccc}
\hline \multirow{2}{*}{ Category of Queens/Colonies } & \multicolumn{2}{c}{ Mean Proportion of Eliminated Queens } \\
\cline { 2 - 4 } & killed in cells & killed in duels & left in 2 swarms \\
\hline All queens eliminated in 13 colonies (n=70 queens) & $44.3 \%$ & $35.7 \%$ & $20.0 \%$ \\
Colonies with pre-emergence destruction (n=9) & $67.6 \%$ & $18.9 \%$ & $13.5 \%$ \\
Colonies with no pre-emergence destruction (n=4) & $0.0 \%$ & $72.7 \%$ & $27.3 \%$ \\
Colonies with queen duels ( $\mathrm{n}=7$ ) & & & \\
Colonies without queen duels (n=6) & $23.7 \%$ & $58.8 \%$ & $17.5 \%$ \\
& $90.0 \%$ & $0.0 \%$ & $10.0 \%$ \\
Colonies with swarm departures (n=6) & & & \\
Colonies without swarm departures (n=7) & $14.6 \%$ & $56.3 \%$ & $29.1 \%$ \\
African colonies (n=7) & $81.8 \%$ & $18.2 \%$ & $0.0 \%$ \\
European colonies (n=6) & & & \\
\hline
\end{tabular}

the number of queens eliminated by duels and swarm departure $(2 \times 2$ Chi-Square test of independence, d.f. $=1, P=0.356)$. African colonies did not differ significantly from European col- onies in the number of queens eliminated in cells, duels, and secondary swarms $(2 \times 3 \mathrm{Chi}-$ Square test of independence, d.f. $=2, P=$ 0.358). Four queen cells (E6c, A1f, A1g, A4i) 
were not included in these analyses because they were destroyed by workers before the first daughter queen emerged (i.e., during the queen rearing stage of colony fission).

\section{DISCUSSION}

\subsection{Queen elimination occurs in two distinct patterns}

The events during queen elimination can be dichotomized into two distinct patterns (Fig. 2): colonies with queen duels ( 7 of 13 colonies) and colonies without queen duels ( 6 of 13 colonies). In colonies with duels, it was most common for the duels to be followed by secondary swarm departures, which were then followed by more duels. In colonies without queen duels, one queen emerged and killed all of her rivals before their emergence, thus becoming the unchallenged heir to the nest. This dichotomy is further supported by the dependency of the number of queens eliminated by duels and preemergence destruction on the production of secondary swarms (Tab. IV). These findings support Visscher's (1993) predictions from a model of the queens' and workers' genetic interests during reproductive fission. His model predicts that, "the first virgin queen to emerge should kill her sisters before they emerge, unless conditions are such (strong colony, good prospects for swarm) that survival of the swarms is substantial relative to the remaining colony". In other words, colonies will have pre-emergence destruction only when they are too weak to produce viable secondary swarms. Our results support this prediction; with one exception (Colony E5, which swarmed following 3 pre-emergence deaths), pre-emergence destruction followed the departure of the final swarm if any secondary swarms were produced at all (Fig. 2). Which trajectory a colony takes is presumably decided by the workers, which either guard queen cells from attack by chasing and biting intruding queens (thus preserving developing queens for duels and secondary swarms) or refrain from chasing and biting intruding queens (thus allowing queens to be killed before emergence). The mechanisms by which such group decisions are made warrant further investigation.

\subsection{The timing of secondary swarm departures is related to the events of queen elimination}

The timing of the departure of secondary swarms was related to several factors. First, the time of day that secondary swarms departed was not random; all nine swarms departed between 0838 and 1256. This suggests that environmental factors such as air temperature and remaining daylight play a significant role in swarm departure (see also Winston, 1987), and thus also in the queen elimination process. Second, the relative timing of secondary swarm departure during the queen-elimination period was bimodally distributed; swarms typically departed near the end of the queen-elimination process (at a mean of $86.9 \%$ of the total duration for colonies that produced one secondary swarm), or, if colony produced two secondary swarms, the first departed about one-third of the way through the process (at a mean of $34.0 \%$ of the total duration) and the second departed near the end (at a mean of $87.9 \%$ of the total duration). Thus, the departure of the colony's last secondary swarm precedes very closely the end of the queen elimination process, which probably reflects the dramatic change in the costs and benefits of queen elimination caused by the departure of a swarm (see Visscher, 1993). Third, the timing of secondary swarm departure may be related to queen emergence. In at least 4 of the 6 colonies that produced a secondary swarm (Colonies E1, E6, A4, and A7), a queen emerged within $20 \mathrm{~min}$ of swarm departure. Since most of these queens emerged just before swarm departure, it is likely that the workers released them in preparation for swarming. Interestingly, when more than one emerged queen was present in the hive during the departure of a secondary swarm, it was common for one of these queens to remain in the hive (this occurred in 4 of the 5 swarms that departed when more than one queen was present in the hive). Earlier-emerging queens did not have a greater chance of remaining in the hive; 2 of the earliest-emerging queens and 2 of the latest-emerging queens remained in their hive following the departure of a secondary swarm. 


\subsection{Queen duels are a common mechanism of elimination and are associated with more secondary swarm departures and less pre-emergence destruction}

All three mechanisms of elimination played a role in the outcome of the queen elimination process. Death in a queen duel was the most common fate for a queen, thus the outcome of duels (which may depend on relative fighting ability, relatedness to workers, and chance; Tarpy and Fletcher, 1998; Gilley, 2001) is likely to significantly impact the outcome of queen elimination. It is still not entirely clear, however, why the workers permit duels to occur. The adaptive benefits of this group decision deserve further study.

The relative contribution of each mechanism to the final outcome of queen elimination differed depending on which of the two trajectories a colony followed; in colonies with queen duels more queens departed with secondary swarms and fewer queens were killed before emergence than in colonies without queen duels. This suggests that queens might maximize their chances of inheriting the nest by adopting a conditional strategy of emerging early in colonies that will not have duels or secondary swarms (thereby avoiding pre-emergence destruction), and emerging late (but not too late) in colonies that have duels and secondary swarms (thereby avoiding duels and swarm departures). First-emerging queens have been shown to have an advantage in queen elimination (Schneider and DeGrandi-Hoffman, 2003), but in our study, first-emerging queens had an advantage only when colonies had no duels, where 5 of 6 first-emerging queens inherited the nest compared to 1 of 7 for colonies with duels. In colonies with duels, the queens that inherited the nest typically emerged last or next to last, following the departure of the final secondary swarm.

\subsection{Workers play a significant but non-lethal role in queen elimination}

None of the 70 queens eliminated in this study was killed by the workers; all queens were either stung by a rival queen, killed before emerging from their cells, or departed in secondary swarms (Tab. III). These results are supported by several other studies of newly emerged queen and worker behavior in observation hives (Gilley, 2001; Schneider et al., 2001; Gilley et al., 2003; Tarpy and Fletcher, 2003; Schneider and DeGrandi-Hoffman, 2003). In these studies, a total of 178 queens were observed for a combined total of approximately 1600 hours, and not once did the workers by themselves kill a virgin queen. Workerqueen interactions might, however, impose costs that negatively affect the queens' chances of surviving queen elimination. For example, emerged queens may be immobilized by workers when defecated upon by another queen (Gilley, 2001; Tarpy and Fletcher, 2003). These queens are often released unharmed, but are sometimes stung by rival queens while immobilized (Gilley, 2001; Tarpy and Fletcher, 2003). Workers also harass newly emerged queens (Gilley, 2001, 2003), but the costliness of these interactions has not been demonstrated. Workers also played a role in determining the outcome of queen elimination by enlarging holes chewed in cells by emerged queens and by destroying cells on their own during the queen rearing stage of reproductive fission (Tab. II, Colony A1; see also Huber, 1814; Allen, 1956; Schneider and DeGrandiHoffman, 2002; Tarpy et al., 2000).

\subsection{Queen elimination in African and European colonies is similar but patterns may differ}

We did not see marked differences in the three mechanisms of queen elimination between what we observed for European bees and what has been reported for African bees. African colonies were more likely than European colonies to complete queen elimination by pre-emergence destruction alone (Fig. 2), yet death by pre-emergence destruction was not significantly more likely for African queens than for European queens (Tab. IV). Though incontrovertible conclusions await larger sample sizes and controlled initial colony conditions, this difference in trajectories between subspecies may be important for understanding the success of A. mellifera scutellata among established European honey bee populations. For example, early emergence may be more important to queen survival in African than European subspecies (DeGrandi-Hoffman et al., 1998), 
while characteristics associated with fighting ability may be more important to queen survival in European subspecies.

\subsection{Priorities for future research}

The results of this study highlight several questions about queen elimination in honey bees that remain unresolved and which we believe should be a priority for future research: (1) what is the underlying cause of the variation among colonies in the relative frequencies of pre-emergence destruction, duels, and secondary swarm departures (e.g., colony condition, environmental circumstances), (2) what is the adaptive value of duels for the workers of a colony, (3) how and to what degree do workers affect the outcome of queen elimination, (4) how might features of queen elimination unique to African honey bees contribute to their success in the New World, and (5) why do honey bees differ from other swarm-founding Hymenopteran species such as ants (Fletcher and Blum, 1983; Bourke and Franks, 1995) and stingless bees (Michener, 1974; Sakagami, 1982), where workers themselves eliminate queens (see also Tarpy and Gilley, 2004).

\section{ACKNOWLEDGEMENTS}

We thank Tom Seeley, Paul Sherman, Kern Reeve, Cole Gilbert, and Bryan Danforth for discussions and helpful comments on the manuscript. The manuscript was also improved by the suggestions of two anonymous reviewers. DCG was supported by NIMH Training Grant T32 MH15793. DRT was supported by NSF grant IBN-973-4181 awarded to H.K. Reeve.

Résumé - Trois mécanismes d'élimination des reines chez les colonies d'abeilles (Apis mellifera) qui essaiment. L'élimination d'une reine est un processus par lequel toutes les reines non accouplées et produites au cours de la scission (essaimage) de la colonie, sauf une, sont éliminées du nid parental. La figure 1 montre comment l'élimination des reines est liée au processus de scission dans une colonie typique d'abeilles. Les reines sont éliminées selon trois mécanismes : les duels reine-reine, les assassinats de reines et le départ avec l'essaim. Nous passons d'abord en revue ce qui est connu concernant chacun de ces mécanismes d'élimination. Puis nous avons utilisé de nouvelles données provenant de colonies logées dans des ruches d'observation qui essaimaient et avons en même temps ré-analysé les données de la littérature pour répondre à cinq questions sur la biologie de l'élimination des reines, que nous considérons comme remarquables: (1) les rôles relatifs des trois mécanismes dans le résultat de l'élimination des reines, (2) le déroulement typique des évènements dans le nid au cours de l'élimination, (3) le rôle joué par les ouvrières (4) l'action de «l'aspersion » (par des matières fécales)sur le résultat de l'élimination, (5) les différences entre les abeilles européennes (Apis mellifera ligustica) et africaines (A. m. scutellata) dans ce processus.

Les tableaux I et II décrivent les évènements qui ont eu lieu au sein des six colonies d'abeilles européennes et des sept colonies d'abeilles africaines. Le tableau III quantifie le nombre de reines éliminées par chaque mécanisme. La figure 2 montre le déroulement des évènements. La largeur de la flèche représente le nombre de colonies qui suit le déroulement indiqué. Les cercles noirs et blancs indiquent pour chaque colonie l'étape finale (i.e. la reine restante qui hérite du nid), à partir de laquelle on peut remonter la séquence des évènements jusqu'au départ de l'essaim primaire.

Nous tirons de nos résultats les conclusions suivantes : (1) les évènements au cours de l'élimination des reines peuvent être divisés en deux séries distinctes : les colonies sans duels de reines, d'où émerge une reine qui assassine toutes ses rivales, et les colonies avec duels de reines, où une suite très variable d'évènements se succèdent incluant le départ d'au moins un essaim secondaire (Fig. 2); (2) le mécanisme d'élimination le plus commun est le duel, mais la contribution de chaque mécanisme au résultat final dépend du déroulement des évènements que suit une colonie ; (3) les ouvrières ne tuent pas les reines et ne les blessent pas sérieusement, mais elles interagissent avec les reines de certaines façons qui peuvent être coûteuses pour les reines ; (4) l'aspersion dans un contexte naturel aboutit à attirer les ouvrières sur la reine aspergée ; (5) les abeilles européennes et africaines utilisent les mêmes mécanismes, mais des différences existent probablement dans la fréquence relative de chacun d'entre eux.

essaimage / élimination des reines / duel de reines / destruction avant l'émergence

Zusammenfassung - Drei Mechanismen zur Entfernung von überzähligen Königinnen in schwärmenden Honigbienenvölkern. Der Erhalt der Monogynie, d.h. nur eine Königin im Volk, bedeutet, dass bei der Teilung der Völker (Schwarmbildung) alle unbegatteten Königinnen außer einer aus dem alten Schwarmvolk entfernt werden. Abb. 1 zeigt die Beziehung der Entfernung von überzähligen Königinnen zum Teilungsvorgang in einem typischen Honigbienenvolk. Die Königinnen können auf drei verschiedene Arten beseitigt werden: durch Königinnenkämpfe, durch Zerstörung vor dem Schlupf und durch Verlassen des Volkes mit 
einem Nachschwarm. Hier beschreiben wir bekannte Daten über alle Beseitigungsvorgänge. Anhand der Analyse neuer Daten von schwärmenden Beobachtungsstöcken und einer Neuanalyse der schon bekannten Daten nehmen wir zu fünf Fragen der Biologie der Königinnenbeseitigung Stellung, die wir für bemerkenswert halten.

Unsere Ergebnisse bestehen aus folgenden Teilen: Tabelle I und II beschreiben Ereignisse, die in 6 Bienenvölkern europäischer Abstammung und 7 Bienenvölkern afrikanischer Abstammung auftreten. Tabelle II gibt für jeden der verschiedenen Mechanismen die Zahlen der beseitigten Königinnen an. Tabelle IV zeigt die mittleren Anteile der mit jedem Mechanismus beseitigten Königinnen für verschiedene Kolonietypen. Abb. 2 zeigt die Abfolge der Ereignisse während der Königinnenbeseitigung, wobei die Breite der jeweiligen Pfeile die Anzahl der Völker repräsentiert, die dem entsprechenden Ereignispfad gefolgt sind. Die schwarzen und weißen Kreise in Abb. 2 zeigen den letzten Schritt für jedes Volk an (z.B. dass die Königin das Volk übernimmt). Von hier aus kann die Ereignisfolge bis zum Auszug des Primärschwarms zurückverfolgt werden.

Aus unseren Ergebnissen ziehen wir die folgenden Schlüsse: (1) Die Ereignisse während der Königinnenbeseitigung folgen zwei deutlich getrennten Mustern. Einerseits gibt es Völker mit Königinnenkämpfen. Dort folgen auf die Kämpfe zumeist Nachschwärme, danach erfolgen weitere Königinnenkämpfe. Andererseits gibt es Völker ohne Königinnenkämpfe, in diesen schlüpft eine Königin und tötet alle ihre Rivalinnen, bevor diese aus den Zellen schlüpften. (2) Der Zeitpunkt, zu dem ein Nachschwarm das Volk verlässt, steht zu den Ereignissen der Königinnenbeseitigung in Beziehung. (3) Königinnenkämpfe sind ein verbreiteter Mechanismus zur Entfernung der Rivalin und sind mit verstärkter Nachschwarmaktivität und geringerer Zerstörung in den Zellen vor dem Schlupf verbunden. (4) Die Arbeiterinnen spielen eine bedeutende, aber nicht tödliche Rolle bei der Königinnenbeseitigung. (5) Der Ablauf Königinnenbeseitigung ist bei europäischen und afrikanischen Honigbienenvölkern ähnlich, allerdings könnte das Muster der Verhaltensabfolge unterschiedlich ausfallen.

Schwärmen / Königinnenbeseitigung / Königinnenkämpfe / Zerstörung vor dem Schlupf

\section{REFERENCES}

Allen M.D. (1956) The behaviour of honeybees preparing to swarm, Br. J. Anim. Behav. 4, 14-22.

Bernasconi G., Bigler L., Hesse M., Ratnieks F.L.W. (1999) Characterization of queen-specific components of the fluid released by fighting honey bee queens, Chemoecology 9, 161-167.
Bernasconi G., Ratnieks F.L.W., Rand E. (2000) Effect of "spraying" by fighting honey bee queens (Apis mellifera L.) on the temporal structure of fights, Insectes Soc. 47, 21-26.

Boch R., Shearer D.A., Shuel R.W. (1979) Octanoic acid and other volatile acids in the mandibular glands of the honey bee Apis mellifera and in royal jelly, J. Apic. Res. 18, 250-252.

Bourke A.F.G., Franks N.R. (1995) Social Evolution in Ants, Princeton University Press, Princeton.

Butz V.M., Dietz A. (1994) The mechanism of queen elimination in two-queen honey bee (Apis mellifera L.) colonies, J. Apic. Res. 33, 87-94.

Caron D.M. (1970) A study of swarming and the behavior of swarming in honey bees, Apis mellifera L, Ph.D. Thesis, Cornell University.

Caron D.M., Greve C.W. (1979) Destruction of queen cells placed in queenright Apis mellifera colonies, Ann. Entomol. Soc. Am. 72, 405-407.

DeGrandi-Hoffman G., Watkins J.C., Collins A.M., Loper G.M., Martin J.H., Arias M.C., Sheppard W.S. (1998) Queen developmental time as a factor in the Africanization of European honey bee (Hymenoptera: Apidae) populations, Ann. Entomol. Soc. Am. 91, 52-58.

Fletcher D.J.C. (1978) Vibration of queen cells by worker honey bees and its relation to the issue of swarms with virgin queens, J. Apic. Res. 17, 1426.

Fletcher D.J.C., Blum M.S. (1983) Regulation of queen number by workers in colonies of social insects, Science 219, 312-314.

Gilley D.C. (1998) The identity of nest-site scouts in honey bee swarms, Apidologie 29, 229-240.

Gilley D.C. (2001) The behavior of honey bees (Apis mellifera ligustica) during queen duels, Ethology 107, 601-622.

Gilley D.C. (2003) Absence of nepotism in the aggressive interactions between workers and dueling queen honeybees, Proc. R. Soc. Lond. B 270 (1528), 2045-2049.

Gilley D.C., Tarpy D.R., Land B.B. (2003) Effect of queen quality on interactions between workers and dueling queens in honeybee (Apis mellifera L.) colonies, Behav. Ecol. Sociobiol. 55, 190196.

Gotwald W.H.Jr. (1995) Army Ants: the Biology of Social Predation, Ithaca, Cornell University Press.

Harano K., Obara Y. (2004) Virgin queens selectively destroy fully matured queen cells in the honeybee Apis mellifera L., Insectes Soc. 51, 253-258.

Hepburn H.R., Radloff S.E. (1998) Honeybees of Africa, Springer-Verlag, Berlin.

Huber F. (1814) New Observations Upon Bees, Hamilton, Illinois, Am. Bee J., translated by Dadant C.P., 1926.

Jeanne R.L. (1991) The swarm-founding Polistinae, in: Ross K.G., Mattews R.W. (Eds.), The Social Biology of Wasps, Cornell University Press, Ithaca, pp. 191-231.

Lindauer M. (1961) Communication Among Social Bees, Harvard University Press, Cambridge. 
Martin P. (1963) The mechanism of colony division in honeybee swarming and a study of the problem of absconding, Insectes Soc. 10, 13-42.

Michener C.D. (1974) The Social Behavior of the Bees, Harvard University Press, Cambridge.

Ohtani T. (1994) Behaviors of adult queen honeybees within observation hives, I. behavior patterns, Humans and Nature 3, 37-77.

Page R.E. Jr., Erickson E.H. (1986) Kin recognition of virgin queen acceptance by worker honey bees (Apis mellifera L.), Anim. Behav. 34, 10611069.

Page R.E. Jr., Blum M.S., Fales H.M. (1988) oAminoacetophenone, a pheromone that repels honeybees (Apis mellifera L.), Experientia 44, 270-271.

Pflugfelder J., Koeniger N. (2003) Fight between virgin queens (Apis mellifera) is initiated by contact to the dorsal abdominal surface, Apidologie 34, 249-256.

Post D.C., Page R.E. Jr., Erickson E.H. (1987) Honeybee (Apis mellifera L.) queen feces: source of a pheromone that repels worker bees, J. Chem. Ecol. 13, 583-591.

Sakagami S.F. (1982) Stingless Bees, in: Hermann H.R. (Ed.), Social Insects, Academic Press, New York, pp. 361-423.

Schneider S.S., DeGrandi-Hoffman G. (2002) The influence of worker behavior and paternity on the development and emergence of honey bee queens, Insectes Soc. 49, 306-314.

Schneider S.S., DeGrandi-Hoffman G. (2003) The influence of paternity on virgin queen success in hybrid colonies of European and African honeybees, Anim. Behav. 65, 883-892.

Schneider S.S., Lewis L.A. (2004) The vibration signal, modulatory communication and the organization of labor in honey bees, Apis mellifera, Apidologie 35, 117-131.

Schneider S.S., Painter-Kurt S., Degrandi-Hoffman G. (2001) The role of the vibration signal during queen competition in colonies of the honeybee, Apis mellifera, Anim. Behav. 61, 1173-1180.
Schneider S.S., DeGrandi-Hoffman G., Smith D.R. (2004) The African honey bee: factors contributing to a successful biological invasion, Annu. Rev. Entomol. 49, 351-376.

Seeley T.D. (1978) Life history strategy of the honey bee, Apis mellifera, Oecologia 32, 109-118.

Tarpy D.R., Fletcher D.J.C. (1998) Effects of relatedness on queen competition within honey bee colonies, Anim. Behav. 55, 537-543.

Tarpy D.R., Hatch S., Fletcher D.J.C. (2000) The influence of queen age and quality during queen replacement in honeybee colonies, Anim. Behav. 59, 97-101.

Tarpy D.R., Fletcher D.J.C. (2003) 'Spraying' behavior during queen competition in honey bees, J. Insect Behav. 16, 425-437.

Tarpy D.R., Gilley D.C. (2004) Group decision making during queen production in colonies of highly eusocial bees, Apidologie 35, 207-216.

Tarpy D.R., Gilley D.C., Seeley T.D. (2004) Levels of selection in a social insect: a review of conflict and cooperation during honey bee (Apis mellifera) queen replacement, Behav. Ecol. Sociobiol. 55, 513-523.

Tiemann K., Brückner D. (1993) Zum Schwarmverhalten der Sizilianischen Honigbiene Apis mellifera sicula (Montagano 1911), Apidologie 24 365-374.

van Veen J.W., Sommeijer M.J. (2000) Colony reproduction in Tetragonisca angustula (Apidae, Meliponini), Insectes Soc. 47, 70-75.

Visscher P.K. (1993) A theoretical analysis of individual interests and intracolony conflict during swarming of honey bee colonies, J. Theor. Biol. 165, 191-212.

Weaver E.C., Weaver N. (1980) Physical domination of workers by young queen honey bee Apis mellifera Hymenoptera Apidae, J. Kans. Entomol. Soc. 53, 752-762.

Winston M.L. (1987) The biology of the honey bee, Harvard University Press, Cambridge. 